\title{
The Role of Putative Phosphatidylserine- Interactive Residues of Tissue Factor on Its Coagulant Activity at the Cell Surface
}

\author{
Shabbir A. Ansari ${ }^{1}$, Usha R. Pendurthi ${ }^{1}$, Prosenjit Sen ${ }^{2}$, L. Vijaya Mohan Rao ${ }^{1}$ * \\ 1 Department of Cellular and Molecular Biology, The University of Texas Health Science Center at Tyler, \\ Tyler, Texas, United Sates of America, 2 Department of Biological Chemistry, Indian Association for the \\ Cultivation of Science, Kolkata, 700032, India \\ *vijay.rao@uthct.edu
}

\section{Abstract}

Exposure of phosphatidylserine (PS) on the outer leaflet of the cell membrane is thought to play a critical role in tissue factor (TF) decryption. Recent molecular dynamics simulation studies suggested that the TF ectodomain may directly interact with PS. To investigate the potential role of TF direct interaction with the cell surface phospholipids on basal TF activity and the enhanced TF activity following the decryption, one or all of the putative PS-interactive residues in the TF ectodomain were mutated and tested for their coagulant activity in cell systems. Out of the 9 selected TF mutants, five of them -TF $\mathrm{S}_{\mathrm{S160A}}, \mathrm{TF}_{\mathrm{S} 161 \mathrm{~A}}, \mathrm{TF}_{\mathrm{S} 162 \mathrm{~A}}$, $\mathrm{TF}_{\mathrm{K} 165 \mathrm{~A}}$, and $\mathrm{TF}_{\mathrm{D} 180 \mathrm{~A}^{-}}$exhibited a similar TF coagulant activity to that of the wild-type TF. The specific activity of three mutants, $\mathrm{TF}_{\mathrm{K} 159 \mathrm{~A}}, \mathrm{TF}_{\mathrm{S} 163 \mathrm{~A}}$, and $\mathrm{TF}_{\mathrm{K} 166 \mathrm{~A}}$, was reduced substantially. Mutation of the glycine residue at the position 164 markedly abrogated the TF coagulant activity, resulting in $\sim 90 \%$ inhibition. Mutation of all nine lipid binding residues together did not further decrease the activity of TF compared to $\mathrm{TF}_{\mathrm{G} 164 \mathrm{~A}}$. A similar fold increase in TF activity was observed in wild-type TF and all TF mutants following the treatment of THP-1 cells with either calcium ionomycin or $\mathrm{HgCl}_{2}$, two agents that are commonly used to decrypt TF. Overall, our data show that a few select TF residues that are implicated in interacting with PS contribute to the TF coagulant activity at the cell surface. However, our data also indicate that TF regions outside of the putative lipid binding region may also contribute to PS-dependent decryption of TF.

\section{Introduction}

Funding: This work was supported by grant support from American Society of Hematology Bridge Grant Award and National Heart, Lung, and Blood Institute grant HL124055 (to LVMR) and American Heart Association, Southwest Affiliate Grant-In-Aid (15GRNT22620004, to UP).

Competing Interests: The authors have declared that no competing interests exist.

Tissue factor (TF), a transmembrane glycoprotein, is the cofactor for the serine protease coagulation factor VIIa (FVIIa). The TF-FVIIa complex formed on the cell surface initiates the coagulation cascade via a limited proteolytic cleavage of clotting proteins, factor IX and factor X, ultimately leading to the formation of fibrin [1]. The formation of the TF-FVIIa complex not only initiates the coagulation process to maintain hemostasis but also transduces cell signaling through the cleavage of protease-activated receptors (PARs) [2,3]. Tissue factor is 
constitutively expressed on the surface of many extravascular cells, including fibroblasts and epithelial cells, but not in cells that come in contact with blood, such as monocytes and endothelial cells [4,5]. However, certain pathological conditions induce TF expression in monocytes and endothelial cells [6-8], which often leads to thrombotic disorders [9-11]. Thus, the precise regulation of TF expression and the activity on the surface of cells is not only essential to hemostasis but also health in general.

The majority of the TF present on the cell surface exists in the cryptic (inactive) state but transforms to the active state (decrypted) following cell activation or injury [12]. Mechanisms that regulate TF activity on the cell surface are not completely understood. Although various mechanisms have been proposed for TF decryption [13-17], exposure of phosphatidylserine (PS) on the outer cell surface membrane following cell perturbation is thought to be predominantly responsible for TF decryption $[13,15,18,19]$. Recent studies of molecular dynamics simulation of the TF ectodomain in solution and on the surface of anionic phospholipids suggested a direct interaction of PS head groups with specific residues in TF [20]. This interaction is thought to contribute to the optimal presentation of the TF exosite region to its protein substrates, factors IX and X, through modulation of conformation-specific changes in TF [20]. These data raise the possibility that a direct interaction between the lipids that have been exposed following cell perturbation and TF may play a role in TF decryption. The subsequent studies using purified TF relipidated in predefined PC/PS vesicles supported the significance of the interaction between a few of these specific amino acid residues in TF and PS for TF activity [21]. However, the involvement of these specific lipid binding residues of TF in TF decryption in a complex biological membrane is unknown.

In the present study, we investigated the potential role of TF direct interaction with the lipids on the cell surface through the putative lipid binding residues in supporting TF activity, both on unperturbed cells and cells stimulated to decrypt TF. For these studies, we generated a panel of plasmid and adenoviral constructs of TF variants and expressed them in two different cell model systems, and then determined their specific activity in unperturbed and perturbed conditions.

\section{Materials and Methods}

\section{Reagents}

Recombinant human FVIIa and affinity purified rabbit anti-human FVIIa polyclonal antibody were provided by the late Walter Kisiel, the University of New Mexico Health Science Center, Albuquerque, NM, USA. Purified human FX was purchased from Enzyme Research Laboratories (South Bend, IN, USA). Purified human FXa was obtained from Haematologic Technologies, Inc. (Essex Junction, VT, USA). Preparation and characterization of monospecific polyclonal antibodies against human TF was described previously [22]. TF10H10 and TF9C3 hybridomas were kindly provided by James H. Morrissey, University of Illinois, College of Medicine, Urbana, IL, USA. TF10H10 and TF9C3 mAbs were purified from mouse ascites fluid using the Affi-Gel Protein A MAPS II Kit from Bio-Rad (Hercules, CA, USA). FuGENE HD transfection reagent was from Promega (Madison, WI, USA). Hygromycin B was from A. G. Scientific (San Diego, CA, USA). $\mathrm{HgCl}_{2}$ and ionomycin were from Sigma-Aldrich (St. Louis, MO. USA). Alkaline phosphatase-labeled Streptavidin and BluePhos Microwell Phosphatase Substrate System were from KPL (Gaithersburg, MD, USA).

\section{Cell culture}

CHO-K1 cells were obtained from the American Type Culture Collection (ATCC, Manassas, VA, USA) and cultured in F-12K medium supplemented with 10\% fetal bovine serum (FBS) 
and $1 \%$ penicillin/streptomycin. Human monocytic leukemia cell line, THP-1, was obtained from ATCC and was cultured in RPMI 1640 medium supplemented with 10\% FBS and 1\% penicillin/streptomycin. Both the cell types were cultured at $37^{\circ} \mathrm{C}$ and $5 \% \mathrm{CO}_{2}$ in a humidified incubator. The cells were washed once with buffer A (10 mM N-2-hydroxyethylpiperazine- $\mathrm{N}^{\prime}$ 2-ethanesulfonic acid [HEPES], $0.15 \mathrm{M} \mathrm{NaCl}, 4 \mathrm{mM} \mathrm{KCl}$, and $11 \mathrm{mM}$ glucose, $\mathrm{pH}$ 7.5) prior to their use in experiments.

\section{Generation of TF mutant constructs by site-directed mutagenesis}

Site-directed mutagenesis was performed using the QuikChange XL II Site-Directed Mutagenesis Kit (Stratagene) following the manufacturer's protocol. The wild-type TF gene was cloned into the expression vector plasmid pcDNA3.1 hygro vector (Invitrogen) and pacAd5 CMVK-NpA shuttle vector (Cell Biolabs, San Diego, CA) and were used as the template for site-directed mutagenesis. To generate the different mutants of TF in the lipid binding region and to mutate all the putative lipid binding residues (LBR), the following synthetic oligonucleotides were designed:

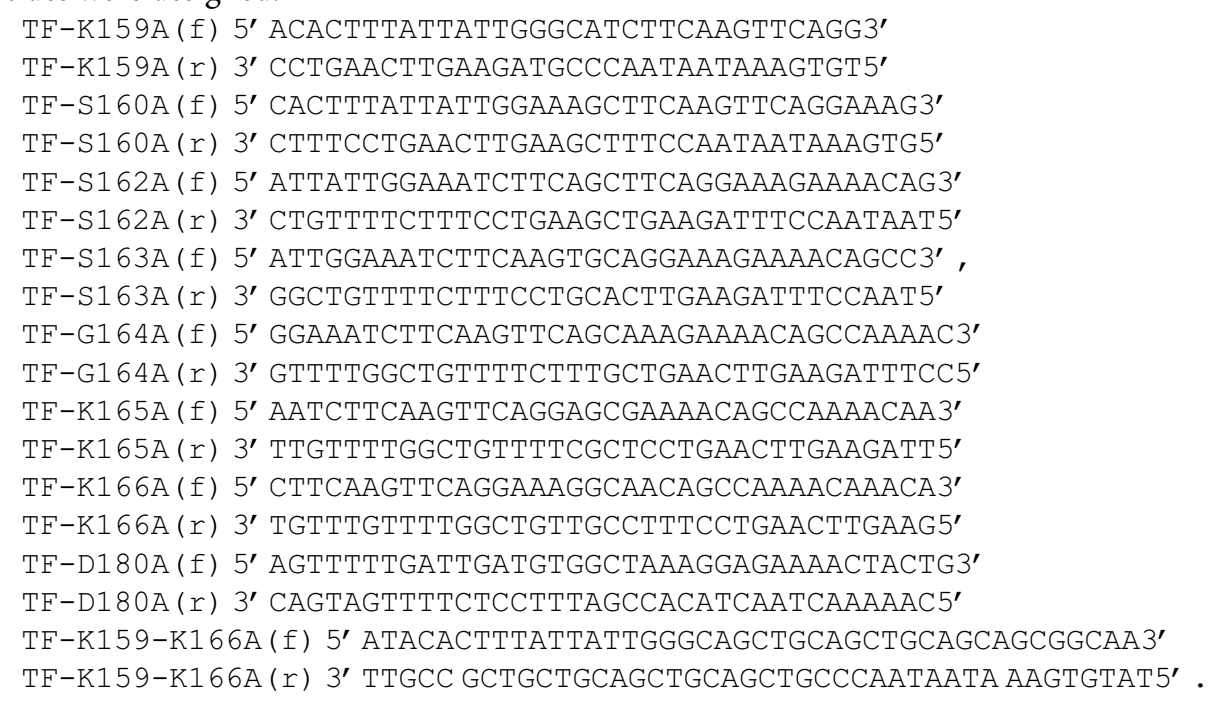

TF-K159-K166A plasmid was used as a template to mutate the aspartate residue at position 180 to alanine to generate the $\mathrm{TF}_{\mathrm{LBR}}$ mutant. All mutations were verified by DNA sequencing of the plasmids (DNA sequencing service was provided by Eurofins MWG/Operon, Huntsville, AL).

\section{Stable expression of TF mutants in $\mathrm{CHO}-\mathrm{K} 1$ cells}

For the generation of stable cell lines, $\mathrm{CHO}-\mathrm{K} 1$ cells were seeded in $60 \mathrm{~mm}$ dishes, and the following day, they were transfected with one $\mu \mathrm{g}$ of plasmid DNA encoding either wild-type TF or one of the TF variants using FuGENE HD transfection reagent. The cells were grown in the presence of hygromycin B $(800 \mu \mathrm{g} / \mathrm{ml})$ containing medium to generate the stable cell lines. Stable cell lines were maintained under the selection pressure with hygromycin $\mathrm{B}$.

\section{Generation of recombinant adenoviral constructs of wild-type TF and TF variants}

TF pacAd5 CMVK-NpA shuttle vector and pacAd5 9.2-100 adenovirus backbone DNA were linearized with $\mathrm{PacI}$ for cotransfection into HEK293 AD cells. Cells were maintained in the incubator at $37^{\circ} \mathrm{C}, 5 \% \mathrm{CO}_{2}$ for $12-14$ days with an addition of $1 \mathrm{ml}$ extra medium intermittently. The cells were harvested as described in the manufacturer's protocol (Cell Biolabs) to 
obtain a high-titer virus. The viral titer was determined by the QuickTiter adenovirus immunoassay kit from Cell Biolabs.

\section{Adenoviral transduction of TF in THP-1 cells}

THP-1 cells $\left(2 \times 10^{5}\right)$ cultured in RPMI serum-rich medium were transduced with either wildtype TF or TF mutant adenoviruses ( $100 \mathrm{moi} / \mathrm{cell}$, the dose was adjusted slightly among various TF variants to obtain similar TF expression levels). The cells were grown for $48 \mathrm{~h}$ and washed twice with buffer A before they were used in experiments.

\section{Determination of ${ }^{125} \mathrm{I}-\mathrm{FV}$ Ila and ${ }^{125} \mathrm{I}-\mathrm{TF}$ mAb binding to cells}

TF mAbs (9C3 and 10H10) and FVIIa were labeled with ${ }^{125}$ I using Iodo-Gen (Thermo Scientific, Rockford, IL, USA)-coated polypropylene tubes and $\mathrm{Na}^{125}$ I (Perkin Elmer, Waltham, MA, USA) according to manufacturer's protocol and as described previously [23,24]. A saturating concentration of the radiolabeled TF $\mathrm{mAb}$ or FVIIa $(10 \mathrm{nM})$ were added to the cells in buffer B (buffer A containing $1 \mathrm{mg} / \mathrm{ml}$ bovine serum albumin [BSA], $5 \mathrm{mM} \mathrm{CaCl}_{2}$ and $1 \mathrm{mM}$ $\mathrm{MgCl}_{2}$ ) and incubated for $2 \mathrm{~h}$ on ice in the cold room. To determine $\mathrm{K}_{\mathrm{d}}$ for FVIIa binding to wild-type TF and TF mutants, cells were incubated with varying concentrations of ${ }^{125}$ I-FVIIa, 1 to $50 \mathrm{nM}$. At the end of $2 \mathrm{~h}$ incubation, the unbound radiolabeled ligand was removed from the cells. Cells were washed four times with ice-cold buffer $\mathrm{B}$ and the bound labeled protein was eluted by adding $100 \mathrm{mM}$ glycine, $\mathrm{pH} 2.3$ for $5 \mathrm{~min}$. In the case of THP- 1 cells, centrifugation was used (2,000 rpm for $4 \mathrm{~min}$ in an Eppendorf microfuge) to remove the unbound radioligand and the cells were washed 3 times with buffer $B$. The radioactivity from the glycine eluate or the total cell pellet was counted in a gamma counter. To determine non-specific binding, parallel binding studies were performed using control cells (cells not transfected with TF constructs), and these values were subtracted from the values obtained in cells transfected to express TF to determine the specific binding.

\section{TF activity assay}

The procoagulant activity of the wild-type and mutant TF was measured in a FX activation assay as described previously [25]. Briefly, the cells were incubated with FVIIa $(10 \mathrm{nM})$ for $5 \mathrm{~min}$ in buffer $\mathrm{B}$ at $37^{\circ} \mathrm{C}$ with gentle shaking. After 5 min incubation, $\mathrm{FX}(175 \mathrm{nM})$ was added to the cells. FXa generation was allowed for $20 \mathrm{~min}$ for CHO-K1 cells and $4 \mathrm{~min}$ for THP-1 cells. During this phase, the rate of FX activation was linear, and only less than $10 \%$ of the substrate was activated. An aliquot removed from the reaction mixture was added to the stopping buffer (Tris-buffered saline containing $1 \mathrm{mg} / \mathrm{ml} \mathrm{BSA}$ and $10 \mathrm{mM}$ EDTA), and the amount of FXa generated was determined in a chromogenic assay with the use of the substrate Chromogenix S2765 as described earlier [25]. To decrypt TF, the cells were stimulated with $100 \mu \mathrm{M} \mathrm{HgCl}_{2}$ for $5 \mathrm{~min}$ or $10 \mu \mathrm{M}$ ionomycin for 10 min just before the addition of FVIIa. A low basal endogenous TF activity of non-transfected THP-1 cells, which represents less than $10 \%$ of the activity observed in cells transduced with wild-type TF, was removed from TF activity measured in THP- 1 cells transfected with wild-type TF and TF mutants to evaluate the specific activity of wild-type and TF mutants.

\section{Data collection and analysis}

All experiments were done in duplicates at least 3 independent times. The data shown in the figures and tables represent mean \pm SEM. When statistical significance was calculated, a t-test was used to determine whether TF activity observed in a TF mutant significantly differs from that of wild-type TF. 


\section{Results}

\section{Effect of specific mutations in the lipid binding region of TF on FX activation in $\mathrm{CHO}-\mathrm{K} 1$ cells}

Based on the recent molecular dynamic simulation studies [20] and studies performed with TF mutants in liposomes [21], we selected 9 different TF amino acid residues that were thought to be involved in TF interaction with anionic lipids to investigate the importance of TF ectodomain interaction with the cell surface membrane lipids on TF procoagulant activity in both basal state and following decryption. In initial studies, we used the $\mathrm{CHO}$ cell system to generate the cells expressing wild-type TF and TF mutant at the cell surface. Although CHO cells were transfected with equal amounts of plasmid DNA of wild-type TF and TF variants under identical experimental conditions, TF protein expression in the transfected cells was varied (data not shown). Therefore, to measure TF functional activity on the surface accurately in cells expressing wild-type TF and TF variants, we quantified TF expression levels at the cell surface by measuring the amount of ${ }^{125}$ I-labeled TF mAb bound to the cells. As shown in Fig $1 \mathrm{~A}$ and $1 \mathrm{~B}$, two
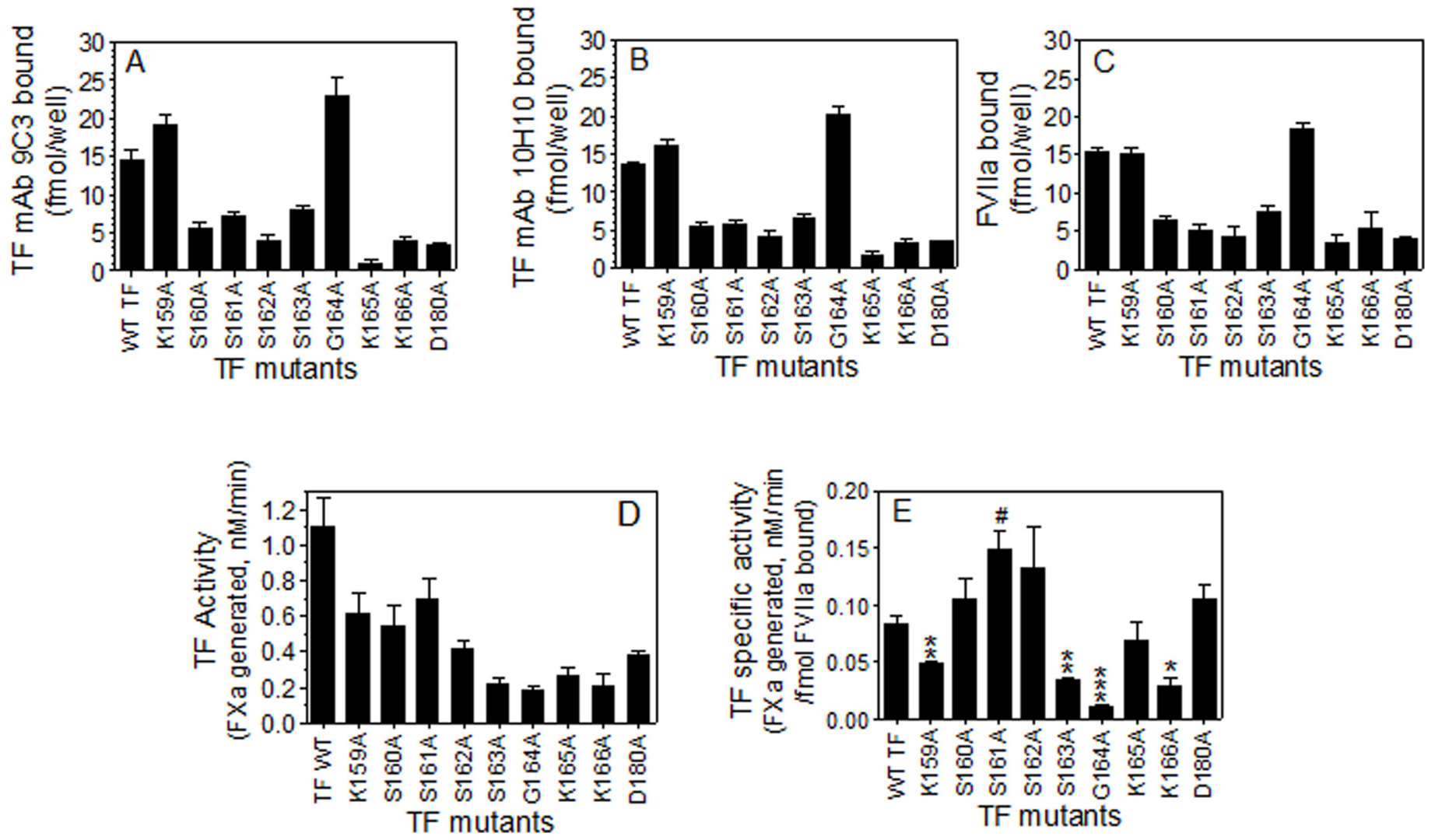

Fig 1. Analysis of tissue factor protein levels, FVIla binding, and the coagulant activity of wild-type TF or lipid-interacting residue mutants of TF in CHO cells. $\mathrm{CHO}$ cells stably transfected to express wild-type TF or mutant TF, or untransfected $\mathrm{CHO}$ cells were incubated with ${ }^{125} \mathrm{I}$-labeled TF mAb $9 \mathrm{C} 3(\mathrm{~A}), 10 \mathrm{H} 10(\mathrm{~B})$ or FVIla $(\mathrm{C})(10 \mathrm{nM})$ at $4^{\circ} \mathrm{C}$ for $2 \mathrm{~h}$ in buffer $\mathrm{B}$. The concentration of the radioligand bound to cell surface TF was determined as described in the Methods. To determine the specific binding, the values obtained with untransfected cells were subtracted from the values obtained in cells expressing wild-type TF or mutant TF. In general, we observed 5 to $8 \%$ of TF mAb and 20 to $30 \%$ of FVIla binding in untransfected cells compared to cells transfected with wild-type TF. (D) CHO cells expressing wild-type TF or a TF mutant were exposed to FVIla (10 nM) and FX (175 nM) for 20 min, and the amount of FXa generated was determined in a chromogenic assay. Panel $E$ depicts the TF activity as calculated by the amount of FXa generated $(\mathrm{nM})$ per fmol TF-FVlla complexes formed on the cell surface. The data shown in the figure represents the mean \pm SEM from 3 independent experiments performed in duplicate. The specific activity of some of the mutants was statistically significantly lower than that of the wild-type TF (t-test). ${ }^{*}, P<0.05 ;{ }^{*}, P<0.01 ; *^{* *}, P<0.001$. \# indicates that specific activity of TF mutants was statistically significantly higher than that of the wild-type TF

doi:10.1371/journal.pone.0158377.g001 
different TF mAb - 10H10 and 9C3-bound to the cells at nearly identical amounts. Next, we investigated FVIIa binding to TF mutants. Since all studies described here employed a FVIIa concentration that is equivalent to the plasma concentration of FVII (10 nM), FVIIa binding studies were carried out at this concentration. As shown in Fig 1C, the level of FVIIa bound to the cells expressing various TF mutants were essentially similar to that of the amount of TF $\mathrm{mAb}$ bound to these cells. These data indicate that all TF variants used in the study had no defect in their ability to interact with FVIIa, at least at the concentration of FVIIa $(10 \mathrm{nM})$ used in the study. Thus, the differences in FVIIa binding levels observed in cells expressing the wildtype and variants reflect the differences in expression levels of TF at the cell surface in the transfected cells and not due to potential differences in FVIIa affinity to bind wild-type TF and TF mutants. Additional studies, in which we investigated FVIIa binding kinetics to wild-type $\mathrm{TF}$ and two select TF mutants $\left(\mathrm{TF}_{\mathrm{S} 160 \mathrm{~A}}\right.$ and $\left.\mathrm{TF}_{\mathrm{G} 164 \mathrm{~A}}\right)$ using varying concentrations of FVIIa (1 to $50 \mathrm{nM}$ ), confirmed that FVIIa bound to TF mutants with a similar affinity as that of wildtype $\mathrm{TF}\left(\mathrm{K}_{\mathrm{d}}\right.$, wild-type $\mathrm{TF}, 4.40 \pm 1.09 \mathrm{nM}$; $\left.\mathrm{TF}_{\mathrm{S} 160 \mathrm{~A}}, 4.23+0.79 \mathrm{nM} ; \mathrm{TF}_{\mathrm{G} 164 \mathrm{~A}}, 4.37 \pm 1.11 \mathrm{nM}\right)$. This observation is consistent with the earlier finding where FVIIa binding to TF mutants was investigated in solution using an amidolytic assay [21]. Thus, the reduced TF activity observed with some of TF variants (Fig 1D) may reflect reduced expression of TF variants, compared to wild-type TF, at the cell surface. Therefore, TF activity was normalized to TF antigen levels and shown as TF specific activity (Fig 1E).

Out of the 9 selected TF mutants, five of them $-\mathrm{TF}_{\mathrm{S} 160 \mathrm{~A}}, \mathrm{TF}_{\mathrm{S} 161 \mathrm{~A}}, \mathrm{TF}_{\mathrm{S} 162 \mathrm{~A}}, \mathrm{TF}_{\mathrm{K} 165 \mathrm{~A}}$, and $\mathrm{TF}_{\mathrm{D} 180 \mathrm{~A}}$ - exhibited a similar or slightly higher TF coagulant activity to that of the wild-type TF. The differences in the TF-specific activity among them are not statistically significant except for one mutant $\left(\mathrm{TF}_{\mathrm{S} 161 \mathrm{~A}}\right)(\mathrm{Fig} 1 \mathrm{E})$. The specific activity of $\mathrm{TF}_{\mathrm{K} 159 \mathrm{~A}}, \mathrm{TF}_{\mathrm{S} 163 \mathrm{~A}}$ and $\mathrm{TF}_{\mathrm{K} 166 \mathrm{~A}}$ mutants was reduced substantially, and in the range of $40 \%-70 \%$ of wild-type TF. Mutation of the glycine residue at the position 164 markedly abrogated the TF coagulant activity, resulting in a $90 \%$ loss of TF-specific activity relative to the TF-specific activity of the wild-type (Fig 1E).

\section{The role of putative lipid interacting residues of TF on TF-FVIla activation of FX in monocytic cells}

Although our earlier studies [26] indicated that TF coagulant activity in various cell types was regulated essentially in a similar manner, other studies in the literature suggest that TF encryption and decryption may vary among various cell types since the fold increase in TF activity following the cell stimulation was much higher in monocytic cells compared to other cell types [27]. Therefore, we next investigated the effect of select mutations in the putative lipid binding region of TF on TF functional activity in THP-1 monocytic cells. Since unperturbed THP-1 cells express very low levels of TF endogenously, it is feasible to transfect these cells with TF mutants to investigate the effect of TF mutations on its functional activity without much interference from the endogenous TF. As THP-1 cells were resistant to plasmid transfection, TF expression was transduced in these cells by adenoviruses encoding the wild-type TF or different mutants of TF. Measurement of TF expression levels showed a similar level of TF expression at the cell surface in cells transduced with adenoviruses encoding wild-type TF and TF variants (Fig 2A). Measurement of cell surface TF activity showed that some of the TF variants exhibited a similar level of TF activity seen with wild-type TF and other variants showed reduced activity (Fig $2 \mathrm{~B}$ ). As observed in the $\mathrm{CHO}$ cell system, $\mathrm{TF}_{\mathrm{S} 160 \mathrm{~A}}, \mathrm{TF}_{\mathrm{S} 162 \mathrm{~A}}$, and $\mathrm{TF}_{\mathrm{D} 180 \mathrm{~A}}$ expressed TF-specific activity equivalent to that of the wild-type $\mathrm{TF}$ whereas $\mathrm{TF}_{\mathrm{K} 159 \mathrm{~A}}, \mathrm{TF}_{\mathrm{S} 163 \mathrm{~A}}$ and $\mathrm{TF}_{\mathrm{K} 166 \mathrm{~A}}$ mutants exhibited significantly reduced cell surface $\mathrm{TF}$ activity compared to that of wild-type TF (40 to $75 \%$ inhibition) (Fig 2C). The mutation of G164 residue abolished the activity of TF by about $90 \%$. Although minor differences exist in the specific activity of TF 


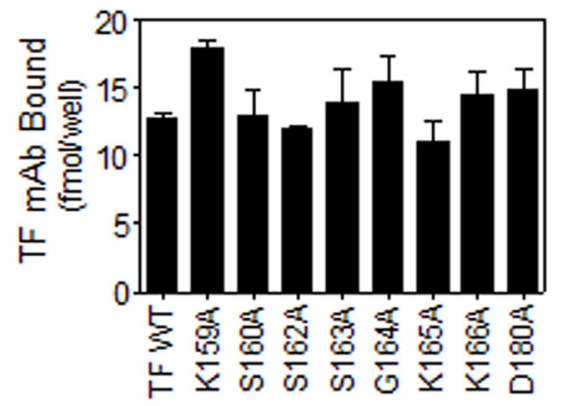

TF mutants

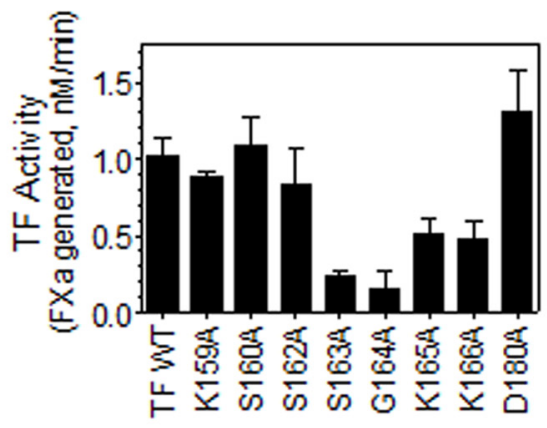

TF mutants

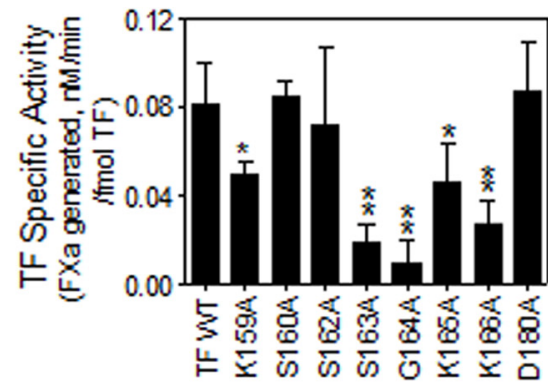

TF mutants

Fig 2. Determination of cell surface TF-specific activity in THP-1 cells transduced to express wild-type TF or TF mutants of lipidinteracting residues. THP-1 cells were transduced with adenovirus encoding wild-type TF or mutant TF. TF protein expression levels on the cell surface were determined by TF mAb $9 \mathrm{C} 3$ binding to the cells $(A)$ and the cell surface TF activity was determined in FXa generation assay (B). TF-specific activity on the cell surface (C) was determined as the amount of FXa generated (nM)/fmol TF. The data shown in the figure represents the mean \pm SEM from 3 independent experiments performed in duplicate. ${ }^{*}, P<0.05 ;{ }^{*}, P<0.01$ compared to the wild-type TF (ttest).

doi:10.1371/journal.pone.0158377.g002

mutants in comparison to wild-type TF in CHO and THP-1 cell systems (Figs 1E and 2C, Table 1), overall the data are consistent in demonstrating that mutation of K159, S163, G164, and K166 residues significantly impaired TF-FVIIa activation of FX whereas mutation of S160, S162 and D180 residues had no significant effect.

To address the concern whether the decreased FXa generation seen with the select TF mutants is due to an impaired substrate interaction with TF-FVIIa complex, we investigated Michaelis-Menten kinetics of FX activation by wild-type TF-FVIIa or mutant TF-FVIIa complexes. For these studies, we selected wild-type TF, two of the TF mutants $\left(\mathrm{TF}_{\mathrm{S} 163 \mathrm{~A}}\right.$ and $\mathrm{TF}_{\mathrm{G} 164 \mathrm{~A}}$ ) that showed a significant decrease in FX activation and one of the TF mutants $\left(\mathrm{TF}_{\mathrm{S} 160 \mathrm{~A}}\right)$ that showed no apparent defect in supporting FX activation. Results of this study suggested that there were no significant statistical differences in Km values between wild-type TF and TF mutants (Table 2).

Table 1. The ability of TF lipid binding mutants to support FX activation on the cell surface, and comparison of the present data to the data obtained in TF liposomes for the same mutants in an earlier study [21].

\begin{tabular}{l|l|l|l}
\hline TF Mutant & CHO $^{\mathbf{a}}$ & THP-1 $^{\mathbf{a}}$ & PC/PS vesicles $^{\mathbf{b}}$ \\
\hline K159A & $49 \pm 3.1$ & $61 \pm 4.3$ & $23 \pm 3.2$ \\
\hline S160A & $118 \pm 4.2$ & $105 \pm 5.7$ & $66 \pm 3.6$ \\
\hline S161A & $141 \pm 18$ & - & 114 \\
\hline S162A & $130 \pm 6.2$ & $89 \pm 26.2$ & $53 \pm 1.3$ \\
\hline S163A & $38 \pm 2.4$ & $23 \pm 6.1$ & $5 \pm 0.7$ \\
\hline G164A & $12 \pm 0.9$ & $11 \pm 7.8$ & $5 \pm 0.5$ \\
\hline K165A & $94 \pm 33.9$ & $57 \pm 8.9$ & $14 \pm 0.7$ \\
\hline D166A & $66 \pm 4.4$ & $34 \pm 5.8$ & $6.4 \pm 0.5$ \\
\hline
\end{tabular}

aData shown was the normalized TF-specific activity, where TF-specific activity observed in cells expressing wild-type TF was taken as $100 \%$. TF-specific activity as calculated by the amount of FXa generated (nM)/fmol TF present on the cell surface. In TF-transfected CHO cells, TF levels at the cell surface were determined in radioligand binding studies using saturating concentrations of two different TF mAb (10H10 and $9 \mathrm{C} 3)$ and FVIla as well as unlabeled FVIla (levels of FVIla bound to TF were determined in ELISA). The mean of all four determinants was taken as the number of TF molecules present on the cell surface to determine TF-specific activity. In THP-1 cells, TF levels at the cell surface were determined in radioligand binding studies employing $9 \mathrm{C} 3 \mathrm{TF} \mathrm{mAb}$. The data shown in the table represent mean \pm SEM from 3 to 6 independent experiments.

${ }^{b}$ Data were mean \pm SD of normalized rates of FX activation of TF mutants relipidated in $5 \% \mathrm{PS} / 95 \% \mathrm{PC}$ vesicles, reported by Ke and Morrissey [21]. 
Table 2. Kinetic constants of TF-FVIla mediated activation of FX in THP-1 cells transduced to express either wild-type TF or putative lipid binding TF mutants $(n=4$; mean \pm SEM).

\begin{tabular}{l|l|l|l}
\hline TF Mutant & Kcat $\left(\mathbf{m i n}^{-1}\right)$ & $\mathbf{K m}(\mathbf{n M})$ & $\left.\mathbf{K c a t} / \mathbf{K m ~}_{(\mathbf{M}}^{-1} \mathbf{S}^{-1}\right)$ \\
\hline WT & $25.33 \pm 0.616$ & $134.40 \pm 17.86$ & $3.15 \times 10^{6}$ \\
\hline S160A & $26.86 \pm 8.22$ & $116.85 \pm 31.07$ & $3.84 \times 10^{6}$ \\
\hline S163A & $8.49 \pm 0.098$ & $139.20 \pm 13.61$ & $1.02 \times 10^{6}$ \\
\hline G164A & $7.68 \pm 0.33$ & $191.20 \pm 12.80$ & $6.71 \times 10^{5}$ \\
\hline
\end{tabular}

doi:10.1371/journal.pone.0158377.t002

\section{The role of lipid-interacting residues of TF in TF decryption}

THP-1 cells expressing wild-type or TF mutants in the putative lipid binding region were treated with calcium ionomycin $(10 \mu \mathrm{M})$ or $\mathrm{HgCl}_{2}(100 \mu \mathrm{M})$ to decrypt TF. As shown in Fig 3 and Table 3, TF coagulant activity of THP-1 cells expressing the wild-type TF was increased by 4-6-fold upon ionomycin treatment, and 8 to 10 -fold following $\mathrm{HgCl}_{2}$ treatment. A higher level of TF decryption in $\mathrm{HgCl}_{2}$-treated cells compared to ionomycin-treated cells may be due to differences in PS exposure at the cell surface or operation of an additional decryption

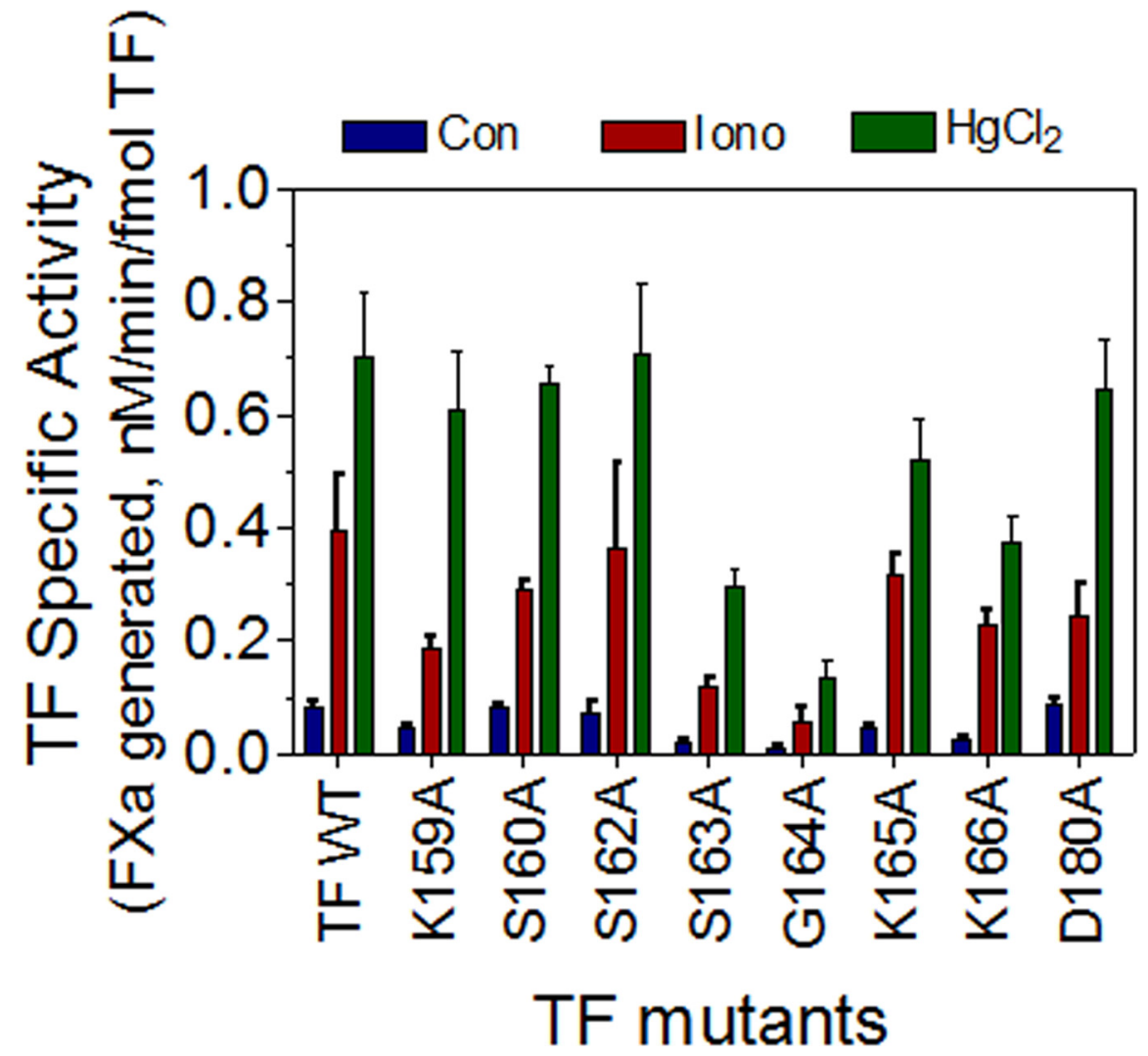

Fig 3. Effect of mutations in the lipid binding residues of TF on its decryption. THP-1 cells transduced to express wild-type TF or TF mutants $\left(1 \times 10^{6} \mathrm{cells} / \mathrm{ml}\right)$ were treated with a control vehicle, calcium ionomycin $\left(10 \mu \mathrm{M}\right.$ for $10 \mathrm{~min}$ ) or $\mathrm{HgCl}_{2}(100 \mu \mathrm{M}$ for $5 \mathrm{~min})$. Then, FVlla $(10 \mathrm{nM})$ and $\mathrm{FX}(175 \mathrm{nM})$ were added to the cells, and the rate of FX activation was measured as described in the Methods. In a parallel experiment, THP-1 cells from the same batch that were used for FX activation studies were incubated with ${ }^{125}$ I-labeled TF mAb $9 \mathrm{C} 3$ for $2 \mathrm{~h}$ at $4^{\circ} \mathrm{C}$ to measure TF protein expression levels on the cell surface. The data obtained in these two assays were used to calculate the specific activity of the wild-type and mutant TF. The data shown in the figure represents the mean \pm SEM from 3 to 6 independent experiments performed in duplicate.

doi:10.1371/journal.pone.0158377.g003 
Table 3. Fold increase in TF coagulant activity of wild-type TF or lipid binding TF mutants following cell stimulation with calcium ionomycin or $\mathrm{HgCl}_{2}$.

\begin{tabular}{l|l|l}
\hline TF Mutant & lonomycin & $\mathbf{H g C l}_{\mathbf{2}}$ \\
\hline WT & $4.9 \pm 1.20$ & $8.7 \pm 1.44$ \\
\hline K159A & $3.8 \pm 0.42$ & $12.4 \pm 2.11$ \\
\hline S160A & $3.5 \pm 0.17$ & $7.8 \pm 0.43$ \\
\hline S162A & $5.1 \pm 2.12$ & $10.0 \pm 1.80$ \\
\hline S163A & $6.5 \pm 0.73$ & $16.3 \pm 1.61$ \\
\hline G164A & $6.5 \pm 2.77$ & $15.2 \pm 3.11$ \\
\hline K165A & $6.9 \pm 0.85$ & $11.5 \pm 1.60$ \\
\hline K166A & $8.5 \pm 0.95$ & $13.8 \pm 1.77$ \\
\hline D180A & $2.8 \pm 0.61$ & $7.4 \pm 1.06$ \\
\hline LBR & $2.2 \pm 0.88$ & $11.1 \pm 1.30$ \\
\hline
\end{tabular}

THP-1 cells expressing wild-type TF or mutant TF were treated with a control vehicle, calcium ionomycin or $\mathrm{HgCl}_{2}$ as described in Fig 3. Fold increase in TF coagulant activity was calculated relative to the TFspecific activity measured in the corresponding wild-type or TF mutant cells treated with a control vehicle (the fold increase shown in the table represents an average of data from 3 to 6 experiments). The foldincrease in TF coagulant activity in various TF mutants did not differ in statistically significant fashion when compared to the fold-increase observed in wild-type TF except in one case ( $\mathrm{S} 163 \mathrm{~A}$ mutant in $\mathrm{HgCl}_{2}$ treatment).

doi:10.1371/journal.pone.0158377.t003

mechanism in $\mathrm{HgCl}_{2}$-treated cells [28]. Calcium ionomycin and $\mathrm{HgCl}_{2}$ also increased the coagulant activity of TF mutants to a similar fold or higher than that observed in wild-type TF. The TF mutant, $\mathrm{TF}_{\mathrm{G} 164 \mathrm{~A}}$, which exhibited a marked loss of $\mathrm{TF}$ activity, also responded robustly to ionomycin and $\mathrm{HgCl}_{2}$ treatments. Ionomycin and $\mathrm{HgCl}_{2}$ treatments increased the TF-specific activity of the mutant by about 6 - and 15-fold, respectively. However, it is important to note that the TF-specific activity of the mutant was still substantially lower compared to the wildtype and other TF mutants. Overall, these data indicate that the mutation of selective residues in the lipid binding region fails to abrogate the PS-dependent TF decryption.

It is possible that interaction of not one, but multiple lipid binding residues with PS may be responsible for TF decryption following the PS exposure. To investigate this, we mutated all putative lipid binding residues in $\mathrm{TF}\left(\mathrm{TF}_{\mathrm{LBR}}, \mathrm{LBR}\right.$, lipid binding region) and used this construct to transduce TF expression in THP-1 cells. As observed with other TF mutants, $\mathrm{TF}_{\mathrm{LBR}}$ mutant is capable of interacting with FVIIa with a similar affinity as that of wild-type TF $\left(\mathrm{K}_{\mathrm{d}}\right.$, wild-type $\mathrm{TF}, 4.4 \pm 1.1 \mathrm{nM}$; $\mathrm{TF}_{\mathrm{LBR}}, 3.9+0.85 \mathrm{nM}$ ). The specific activity of $\mathrm{TF}_{\mathrm{LBR}}$ was markedly lower than that of the wild-type TF. Nonetheless, this mutant still exhibited about 10 to $15 \%$ of the activity of wild-type $\mathrm{TF}$, similar to that of $\mathrm{TF}_{\mathrm{G} 164 \mathrm{~A}}$. More importantly, $\mathrm{TF}$ activity of $\mathrm{TF}_{\mathrm{LBR}}$ mutant also increased its activity by many fold in THP-1 cells following the stimulation with ionomycin or $\mathrm{HgCl}_{2}$ treatment (Fig 4), indicating that the mutant could undergo decryption.

Next to investigate whether the increased TF activity in cells expressing $\mathrm{TF}_{\mathrm{LBR}}$ treated with $\mathrm{HgCl}_{2}$ was dependent on the increased PS or independent of PS, both the control and $\mathrm{HgCl}_{2}$ treated cells were incubated with annexin V to block the PS before adding FVIIa and FX. As shown in Fig 5, annexin V markedly diminished TF-FVIIa activation of FX in both the cell types, either expressing wild-type $\mathrm{TF}$ or $\mathrm{TF}_{\mathrm{LBR}}$, under the basal condition as well in $\mathrm{HgCl}_{2}$ treated cells. In additional studies, we examined the concentration dependence of annexin $\mathrm{V}$ on inhibiting TF and prothrombinase activities of THP- 1 cells expressing wild-type TF and $\mathrm{TF}_{\mathrm{LBR}}$. These studies showed that annexin $\mathrm{V}$ inhibited both $\mathrm{TF}$ (Fig 6A) and prothrombinase (Fig 6B) activity of wild-type and $\mathrm{TF}_{\mathrm{LBR}}$ in a similar concentration-dependent manner on 


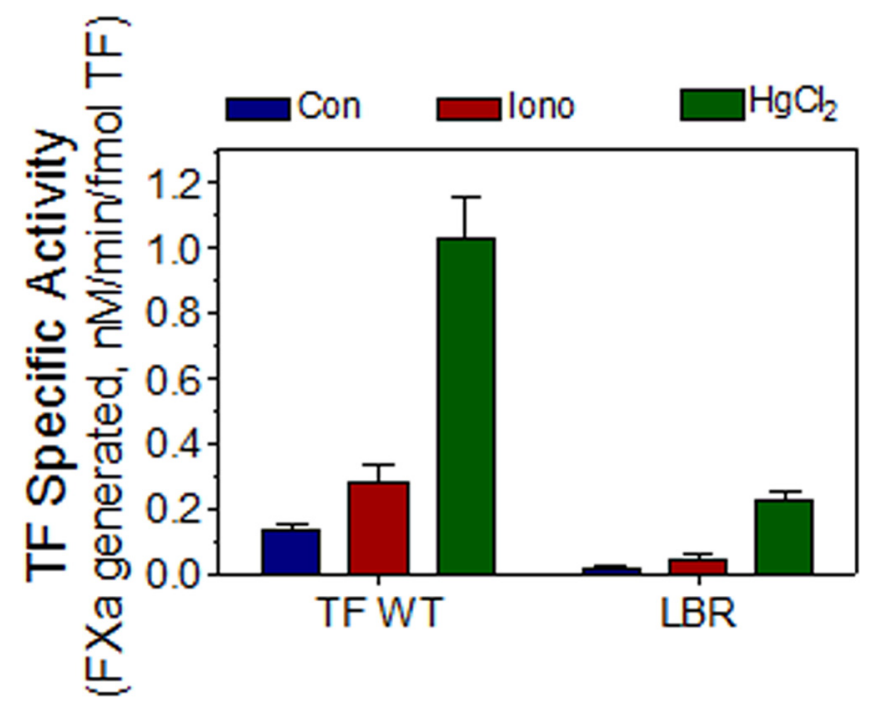

Fig 4. Mutation of multiple putative membrane binding residues of TF fails to abrogate the increased TF procoagulant activity following its decryption. To generate the lipid binding region mutant (LBR) of TF, all amino acid residues in the lipid binding region, i.e., K159 to K166 and D180, were mutated to alanine. The experiment was carried out essentially as described in the legend to Fig 3. Results were presented as means \pm SEM of six independent experiments except the control, which was the mean of five experiments.

doi:10.1371/journal.pone.0158377.g004

unperturbed cells. A $25 \mathrm{nM}$ of annexin $\mathrm{V}$ inhibited both the activities by about $75 \%$, and the inhibition reached almost $100 \%$ at $400 \mathrm{nM}$ of annexin V (Fig 6A). This reflects availability of a basal level of PS at the cell surface of unperturbed cells and its role in supporting TF and prothrombinase activities on unperturbed cells. In cells treated with $\mathrm{HgCl}_{2}$, a much higher concentration of annexin $\mathrm{V}$ was required to inhibit both the TF and prothrombinase activity (Fig 6B).

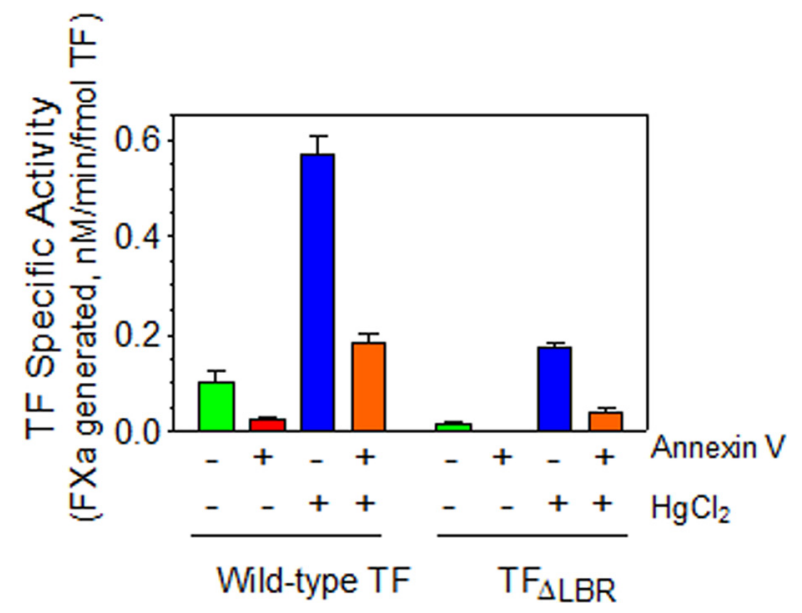

Fig 5. PS-dependent decryption of TF mutant lacking the PS-interactive residues. THP-1 cells expressing equal amounts of wild-type TF (TF WT) or TF mutant of the lipid binding region $\left(T_{\mathrm{LBR}}\right)$ were treated with a control vehicle or $\mathrm{HgCl}_{2}(100 \mu \mathrm{M}$ for $5 \mathrm{~min})$ in the presence or absence of annexin $\mathrm{V}(400 \mathrm{nM})$. TF-FVIla activation of FX was measured by adding FVIla $(10 \mathrm{nM})$ and FX $(175 \mathrm{nM})$ to the cells. In parallel wells, cells were incubated with ${ }^{125}$ I-labeled TF mAb $9 \mathrm{C} 3$ to measure TF protein expression levels on the cell surface. The data obtained in these two assays were used to calculate the specific activity of wild-type and mutant TF. The data shown in the figure represents the mean \pm SEM from 3 independent experiments performed in duplicate.

doi:10.1371/journal.pone.0158377.g005 

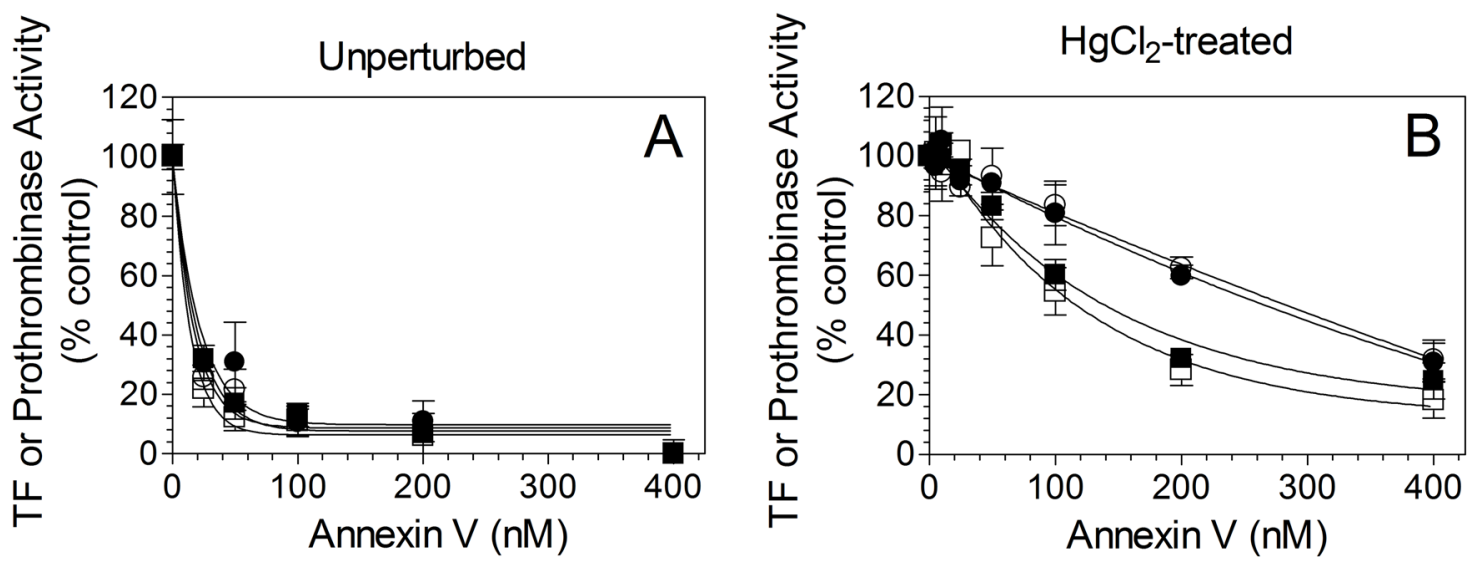

Fig 6. Annexin $\mathrm{V}$ inhibition of tissue factor and prothrombinase activities in unperturbed and $\mathrm{HgCl}_{2}$-treated cells. THP-1 cells were transduced to express equal amounts of wild-type TF or LBR mutant. The cells were incubated with varying concentrations of annexin $\mathrm{V}$ and treated with a control vehicle (A) or $\mathrm{HgCl}_{2}, 100 \mu \mathrm{M}$ for $5 \mathrm{~min}(\mathrm{~B})$. TF-FVIIa activation of FX was measured by adding FVIla $(10 \mathrm{nM})$ and $F X(175 \mathrm{nM})$ and measuring the amount of FXa generated in a chromogenic assay. Prothrombinase activity was measured by adding $\mathrm{FVa}(10 \mathrm{nM}), \mathrm{FXa}(0.1 \mathrm{nM})$, and prothrombin (1. $4 \mu \mathrm{M}$ ) and measuring thrombin generation in a chromogenic assay. As expected, $\mathrm{HgCl}_{2}$ treatment increased TF activity and prothrombinase activity by about 10-fold. To compare annexin V inhibition of TF activity and prothrombinase activity, the activity observed in the absence of annexin $V$ for each set was taken as $100 \%$. Squares ( $\square, \square)$ represent TF activity, and circles $(\circ, \bullet)$ represent prothrombinase activity. Open symbols $(\square, 0)$ represent THP-1 cells transduced to express wildtype TF, and the closed symbols denote THP-1 cells transduced to express LBR mutant. The data shown in the graph represents mean \pm SEM of three independent experiments.

doi:10.1371/journal.pone.0158377.g006

This was expected since $\mathrm{HgCl}_{2}$ treatment was shown to increase PS exposure at the cell surface [25] and thus requires a higher concentration of annexin V to block the increased PS levels at the cell surface. Measurement of prothrombinase activity, as the indicator of PS levels on the cell surface, showed 8 to 10 -fold increase in the prothrombinase activity in $\mathrm{HgCl}_{2}$-treated cells compared to unperturbed cells (thrombin generated $\mathrm{U} / \mathrm{ml} / \mathrm{min}$, unperturbed cells $7.4 \pm 0.75$; $\mathrm{HgCl} 2$ treated cells, $65.3 \pm 4.17 ; \mathrm{n}=3$ ). The failure of annexin $\mathrm{V}$ to completely inhibit $\mathrm{HgCl}_{2}$ induced increase in TF activity and prothrombinase (Figs 5 and 6B) may reflect the inability of annexin $\mathrm{V}$ to access readily all PS sites on the membrane at the concentrations used or a fraction of $\mathrm{HgCl}_{2}$-enhanced activities may be PS-independent as suggested earlier by others [28]. In additional studies, we investigated the effect of annexin V on FVIIa binding to THP-1 cells expressing wild-type $\mathrm{TF}$ or $\mathrm{TF}_{\mathrm{LBR}}$. As noted in our earlier studies in other cell model systems [25,29], annexin V had no significant effect on FVIIa binding to TF, either the wild-type TF or the $\mathrm{TF}_{\mathrm{LBR}}$ mutant, on THP-1 cells (data not shown).

Next, we investigated whether the enhanced TF-FVIIa activation of FX following the PSdependent TF decryption stemmed from the increased catalytic activity of TF-FVIIa complex and not from the enhanced affinity of the substrate to the enzyme complex due to an increased FX binding to PS exposed on the cell surface. For this, we measured the kinetic constants of TF-FVIIa activation of $\mathrm{FX}$ in unperturbed and $\mathrm{HgCl}_{2}$-treated THP-1 cells expressing either wild-type $\mathrm{TF}$ or $\mathrm{TF}_{\mathrm{LBR}}$ mutant. As shown in Table $4, \mathrm{HgCl}_{2}$ treatment increased the catalytic activity of both wild-type $\mathrm{TF}$ and $\mathrm{TF}_{\mathrm{LBR}}$ mutant but had no significant effect on the Km values of TF-FVIIa activation of FX. Therefore, it is unlikely that a potential increase in FX binding to the PS exposed following $\mathrm{HgCl}_{2}$ treatment was responsible for TF decryption. Overall, these data indicate that $\mathrm{TF}_{\mathrm{LBR}}$ mutant could undergo PS-dependent decryption following $\mathrm{HgCl}_{2}$ treatment. This suggests that the interaction of TF region other than the LBR with PS may be responsible for the enhanced TF activity following PS exposure. 
Table 4. Kinetic constants of TF-FVlla mediated activation of $\mathrm{FX}$ in unperturbed and $\mathrm{HgCl}_{2}$-treated THP-1 cells.

\begin{tabular}{l|l|l|l|l}
\hline TF Mutant & Treatment & Kcat $\left(\mathbf{m i n}^{-1}\right)$ & Km (nM) & Kcat/Km $\left(\mathbf{M}^{-1} \mathbf{S}^{-1}\right)$ \\
\hline TF WT & Control & $18.8 \pm 3.25$ & $186.6 \pm 27.1$ & $1.68 \times 10^{6}$ \\
\hline TF WT & $\mathrm{HgCl}$ & $232.8 \pm 45.18$ & $137.4 \pm 6.8$ & $2.82 \times 10^{7}$ \\
\hline TF $_{\text {LBR }}$ & Control & $1.1 \pm 0.27$ & $196.0 \pm 39.2$ & $9.02 \times 10^{4}$ \\
\hline TF $_{\text {LBR }}$ & $\mathrm{HgCl}$ & $222.6 \pm 57.6$ & $4.36 \times 10^{5}$ \\
\hline
\end{tabular}

THP-1 cells were transduced to express either wild-type TF (TF WT) or TF mutant of the lipid binding region (TF vehicle or $\mathrm{HgCl}_{2}(100 \mu \mathrm{M})$ for 5 min and assayed for TF coagulant activity in the presence of FVIla (10 nM) and varying concentrations of FX (25 to 1000 $\mathrm{nM})(\mathrm{n}=6$, mean $\pm \mathrm{SEM})$.

\section{Discussion}

It is generally accepted that most of the TF molecules on the surface of a resting cell exist in an encrypted state with very little procoagulant activity and that this state of TF must undergo decryption to become fully active $[12,13]$. Although a number of distinctive mechanisms have been proposed for TF decryption, most of the evidence in the literature suggests that levels of anionic phospholipids, such as phosphatidylserine (PS), in the outer leaflet of the plasma membrane regulates the activity status of TF at the cell surface [12]. It is well established that PS markedly enhances the enzymatic activity of TF-FVIIa towards its substrates, factors IX and X [13,30-32], but the molecular mechanisms by which PS augments the enzymatic activity of TF-FVIIa is not entirely known. Although the binding of FVIIa and FX to PS via the Gla ( $\gamma$ carboxyglutamic acid) domain and spatial stabilization of the FVIIa catalytic site subsequent to its binding to TF contribute to a marked increase in TF-FVIIa activation of FX [30,33], they do not fully explain the increased TF-FVIIa activation of FX following TF decryption [12]. We speculated earlier that direct TF interaction with anionic phospholipids on the cell surface may play a critical role in regulating TF activity $[23,34]$.

Recently, Ohkubo et al. [20], based on molecular dynamics simulations of the TF ectodomain on the membrane surface, identified direct interactions between certain TF residues and PS head groups on the membrane. In subsequent studies, it was shown that mutation of some of the TF residues predicted to interact with PS, particularly mutations in or near the flexible loop from Lys 159 to Gly 164, decreased the activity of TF incorporated into PS/PC liposomes [21]. In the present study, we investigated the potential contribution of interaction of these putative membrane interactive residues of TF with the cell surface membrane lipids in supporting TF activity. Our studies revealed that mutation of a few select PS interactive residues in TF reduced the activity of TF on the cell surface. Mutation of K159, S163, and K166 reduced the activity of TF between 40 to $75 \%$ of the wild-type whereas G164 mutation decreased the activity by about $90 \%$. Our present data show that the relative contribution of PS-interacting residues of TF in supporting TF activity at the cell surface may vary from that of their effect on TF activity in solution or liposomes. When TF mutants of PS-interacting residues were incorporated into 5\% PS/95\% PC liposomes, five of the mutants-K159A, S163A, G164A, K165A, and K166A -showed a marked impairment in their ability to support TF-FVIIa activation of FX ( 5\% for S163A, G164A, and K166A; 15 to 25\% for K159A and K165A compared to wild-type TF) [21]. However, at the cell surface, the defect in K159A, K165A and K166A mutants in supporting FX activation was not as severe as that observed in liposomes. A number of reports in the literature showed that a single mutation, either of K165 or K166, resulted in an almost complete loss ( $95 \%)$ of TF activity in the relipidated system [21,35-37]. The addition of PS was shown to only partially restore the activity of the single mutants $[21,35]$. In contrast, a single mutation of K165 or K166 in TF had only a modest effect on the activity of TF at the cell 
surface. Our present data of these mutants in the cell system were consistent with an earlier observation [35]. These data suggest that the interaction of one of the lysine residues with the cell surface membrane may be sufficient to induce necessary conformational change in TF-FVIIa exosite to recognize the substrate. It is possible that these lysine residues could interact with other negatively charged membrane components present on the cell surface and this interaction could induce necessary conformational changes in TF for its activity.

The marked defect in the activity of $\mathrm{TF}_{\mathrm{G} 164 \mathrm{~A}}$ mutant at the cell surface probably reflects the importance of this residue in the substrate recognition independent of the phospholipid membrane surface since a similar severe impairment of the activity was observed in this mutant both in solution (phospholipid-free) and in the presence of phospholipids [21,38]. However, we did not find any significant differences in the $k_{m}$ of $\mathrm{TF}_{\mathrm{G} 164 \mathrm{~A}}$-FVIIa activation of $\mathrm{FX}$ vs. wildtype TF-FVIIa activation of FX. G164 residue is located in the surface-exposed loop of TF. Being the smallest amino acid with a minimal side chain, the glycine residue in the loop may allow the necessary flexibility to TF to have the optimal configuration of TF-FVIIa complex to activate the substrate effectively [38]. Furthermore, recent studies showed that G164 plays a critical role in $\mathrm{Mg}^{2+}$-dependent rate enhancement of TF-FVIIa activation of FX [39]. One or both of the above reasons could be responsible for the marked decrease in TF activity in G164A mutant.

Mutation of S162 and D180 residues in the putative lipid binding region of TF had no effect on the activity of TF at the cell surface. These mutations were shown to decrease TF activity by about 40 to $50 \%$ in solution or liposomes [21]. It is interesting to note that mutation of all eight residues in TF that were shown to interact with PS and contribute to the exosite binding of the substrate did not fully abrogate the TF-FVIIa activation of FX on the cell surface, indicating that the residues outside of the lipid binding region may also contribute to TF interaction with the membrane and the substrate recognition.

As expected, decryption of wild-type TF in monocytic cells upon exposure to calcium ionomycin or $\mathrm{HgCl}_{2}$ increased the cell surface TF activity by $\sim 5$ and 10 -fold, respectively. Interestingly, decryption of TF mutants, either mutation of a single amino acid residue in the putative lipid binding region or mutation of all critical residues in the lipid binding region, also increased the TF activity to a similar fold. These data are somewhat surprising since one would expect that the blockage of the direct interaction of TF with the PS exposed on the cell surface by mutating the putative lipid binding residues would block the PS-dependent increased TF activity. These data suggest that either increased PS following $\mathrm{HgCl}_{2}$ treatment is not responsible for the increased TF activity or the presumed interaction of the PS-interacting residues in the TF ectodomain with the membrane PS is not essential for TF decryption. We can rule out the former possibility because inhibition of PS on the cell surface with annexin V blocked the enhanced TF activity of both wild-type $\mathrm{TF}$ and $\mathrm{TF}_{\mathrm{LBR}}$, indicating the decryption of $\mathrm{TF}_{\mathrm{LBR}}$ is dependent on PS. It is possible that other putative PS-interacting residues that are not examined in the present study or residues that are yet to be identified for their membrane interaction potential might have contributed for PS-dependent decryption of $\mathrm{TF}_{\mathrm{LBR}}$.

Although it is generally accepted that TF on cell surfaces must undergo decryption to express maximal coagulant activity, mechanisms that are responsible for TF decryption are not well understood. A majority of the evidence in the literature suggests that levels of anionic phospholipids, such as PS, in the outer leaflet of the plasma membrane play a critical role in regulating TF procoagulant activity at the cell surface [12]. However, other mechanisms-such as thiol-disulfide exchange pathways involving protein disulfide isomerase (PDI), the thioredoxin system, cholesterol content in the plasma membrane and post-translational modifications of TF-may also contribute to TF decryption $[14,15,40]$. Although our studies failed to support [25,41], it had been reported earlier that $\mathrm{HgCl}_{2}$-mediated decryption was largely 
independent of PS [28]. TF decryption induced by calcium ionophore was also shown to be partly independent of PS [42]. Since the majority of the increased TF activity following $\mathrm{HgCl}_{2}$ treatment was blocked by annexin V, the protein that specifically binds PS, it is unlikely that near normal decryption of TF mutants of the lipid binding region following $\mathrm{HgCl}_{2}$ or ionomycin treatment could be largely independent of PS.

Overall, our present data suggest that a few select amino acid residues in TF ectodomain that are implicated in interacting directly with PS contribute to the TF coagulant activity at the cell surface. However, the regulation of TF activity at the cell surface milieu may be different from that of PC/PS vesicles. The potential interaction of the putative PS-interacting residues of TF with cell surface membrane lipids appears to be less critical than with lipids in the liposomes in supporting TF activity. PS-dependent decryption of TF on the cell surface does not depend solely on the interaction between the putative PS interactive residues of TF with PS exposed on cells following cell activation. It is possible that a TF region other than recently identified LBR may also be responsible for enhancing the TF activity following the PS exposure. Further studies are required to understand fully the structure/function relation of TF at the cell surface.

\section{Acknowledgments}

The authors thank the late Walter Kisiel, University of New Mexico, Albuquerque, NM for providing recombinant FVIIa and affinity-purified FVII antibodies, and James H. Morrissey, the University of Illinois at Urbana-Champaign, Urbana, IL for providing TF hybridomas. The authors also thank Morrissey for his critical reading of the manuscript and providing valuable suggestions. We acknowledge the contribution of Sion Williams in proof-reading the manuscript.

\section{Author Contributions}

Conceived and designed the experiments: SAA URP PS LVMR. Performed the experiments: SAA. Analyzed the data: SAA URP LVMR. Contributed reagents/materials/analysis tools: SAA URP. Wrote the paper: SAA LVMR. Read the manuscript and provided suggestions to improve it: URP PS. Designed the primers and helped in generating TF plasmid and adenoviral vectors: URP.

\section{References}

1. Rapaport SI, Rao LVM: The tissue factor pathway: How it has become a "prima ballerina". Thromb Haemost 1995; 74:7-17. PMID: 8578528

2. Ruf W, Dorfleutner A, Riewald M: Specificity of coagulation factor signaling. J Thromb Haemost 2003; 1:1495-1503. PMID: 12871285

3. Rao LVM, Pendurthi UR: Tissue factor-factor VIla signaling. Arterioscler Thromb Vasc Biol 2005; 25:47-56. PMID: 15569823

4. Drake TA, Morrissey JH, Edgington TS: Selective cellular expression of tissue factor in human tissues: Implications for disorders of hemostasis and thrombosis. Am J Pathol 1989; 134:1087-1097. PMID: 2719077

5. Fleck RA, Rao LVM, Rapaport SI, Varki N: Localization of human tissue factor antigen by immunostaining with monospecific, polyclonal anti-human tissue factor antibody. Thromb Res 1990; 59:421-437. PMID: 2237820

6. Contrino J, Hair G, Kreutzer DL, Rickles FR: In situ detection of tissue factor in vascular endothelial cells: Correlation with the malignant phenotype of human breast disease. Nature Medicine 1996; 2:209-215. PMID: 8574967

7. Solovey A, Gui L, Key NS, Hebbel RP: Tissue factor expression by endothelial cells in sickle cell anemia. J Clin Invest 1998; 101:1899-1904. PMID: 9576754 
8. Osterud B, Flaegstad T: Increased thromboplastin activity in monocytes of patients with meningococcal infection: Related to an unfavorable prognosis. Thromb Haemost 1983; 49:5-7. PMID: 6845273

9. Williams JC, Mackman N: Tissue factor in disease and health. Front Biosci 2012; E4:358-372.

10. Ruf W, Yokota N, Schaffner F: Tissue factor in cancer progression and angiogenesis. Thromb Res 2010; 125 Suppl 2:S36-S38. doi: 10.1016/S0049-3848(10)70010-4 PMID: 20434002

11. Rao LVM: Tissue factor as a tumor procoagulant. Cancer and Metastasis Reviews 1992; 11:249-266. PMID: 1423817

12. Rao LV, Pendurthi UR: Regulation of tissue factor coagulant activity on cell surfaces. J Thromb Haemost 2012; 10:2242-2253. doi: 10.1111/jth.12003 PMID: 23006890

13. Bach RR: Tissue factor encryption. Arterioscler Thromb Vasc Biol 2006; 26:456-461. PMID: 16397140

14. Chen VM, Hogg PJ: Encryption and decryption of tissue factor. J Thromb Haemost 2013; 11 Suppl 1:277-284. doi: 10.1111/jth.12228 PMID: 23809131

15. Rao LV, Kothari H, Pendurthi UR: Tissue factor encryption and decryption: facts and controversies. Thromb Res 2012; 129 Suppl 2:S13-S17. doi: 10.1016/j.thromres.2012.02.021 PMID: 22398016

16. Versteeg $\mathrm{HH}$, Ruf $\mathrm{W}$ : Thiol pathways in the regulation of tissue factor prothrombotic activity. Curr Opin Hematol 2011; 18:343-348. doi: 10.1097/MOH.0b013e32834981 de PMID: 21778880

17. Popescu NI, Lupu C, Lupu F: Role of PDI in regulating tissue factor: FVIla activity. Thromb Res 2010; 125 Suppl 1:S38-S41. doi: 10.1016/j.thromres.2010.01.034 PMID: 20163832

18. Rao LVM, Kothari H, Pendurthi UR: Tissue factor: Mechanisms of decryption. Front Biosci 2012; E4:1513-1527.

19. Butenas S, Orfeo T, Mann KG: Tissue factor in coagulation: Which? Where? When? Arterioscler Thromb Vasc Biol 2009; 29:1989-1996. doi: 10.1161/ATVBAHA.108.177402 PMID: 19592470

20. Ohkubo YZ, Morrissey JH, Tajkhorshid E: Dynamical view of membrane binding and complex formation of human factor VIla and tissue factor. J Thromb Haemost 2010; 8:1044-1053. doi: 10.1111/j.15387836.2010.03826.x PMID: 20180816

21. Ke K, Yuan J, Morrissey JH: Tissue factor residues that putatively interact with membrane phospholipids. PLoS One 2014; 9:e88675. doi: 10.1371/journal.pone.0088675 PMID: 24516673

22. Rao LVM: Characterization of anti-tissue factor antibody and its use in immunoaffinity purification of human tissue factor. Thromb Res 1988; 51:373-384. PMID: 3187961

23. Le DT, Rapaport SI, Rao LVM: Relations between factor VIla binding and expression of factor VIla/tissue factor catalytic activity on cell surfaces. J Biol Chem 1992; 267:15447-15454. PMID: 1639786

24. Kothari H, Nayak RC, Rao LV, Pendurthi UR: Cystine186-cystine 209 disulfide bond is not essential for the procoagulant activity of tissue factor or for its de-encryption. Blood 2010; 115:4273-4283. doi: 10. 1182/blood-2009-09-241356 PMID: 20237315

25. Pendurthi UR, Ghosh S, Mandal SK, Rao LV: Tissue factor activation: is disulfide bond switching a regulatory mechanism? Blood 2007; 110:3900-3908. PMID: 17726162

26. Kothari $\mathrm{H}$, Pendurthi UR, Rao LV: Analysis of tissue factor expression in various cell model systems: cryptic vs. active. J Thromb Haemost 2013; 11:1353-1363. doi: 10.1111/jth.12272 PMID: 23621622

27. Liang HPH, Hogg PJ: Critical importance of the cell system when studying tissue factor de-encryption. Blood 2008; 112:912-913. doi: 10.1182/blood-2008-05-156877 PMID: 18650465

28. Chen VM, Ahamed J, Versteeg HH, Berndt MC, Ruf W, Hogg PJ: Evidence for activation of tissue factor by an allosteric disulfide bond. Biochem 2006; 45:12020-12028.

29. Rao LVM, Tait JF, Hoang AD: Binding of annexin V to a human ovarian carcinoma cell line (OC-2008). Contrasting effects on cell surface factor VIla/tissue factor activity and prothrombinase activity. Thromb Res 1992; 67:517-531. PMID: 1448786

30. Morrissey JH, Tajkhorshid E, Sligar SG, Rienstra CM: Tissue factor/factor VIla complex: role of the membrane surface. Thromb Res 2012; 129 Suppl 2:S8-10. doi: 10.1016/j.thromres.2012.02.019 PMID: 22417943

31. Shaw AW, Pureza VS, Sligar SG, Morrissey JH: The local phospholipid environment modulates the activation of blood clotting. J Biol Chem 2007; 282:6556-6563. PMID: 17200119

32. Neuenschwander PF, Bionco-Fisher E, Rezaie AR, Morrissey JH: Phosphatidylethanolamine augments factor VIla-tissue factor activity: Enhancement of sensitivity to phosphatidylserine. Biochem 1995; 34:13988-13993.

33. Morrissey JH, Neuenschwander PF, Huang Q, McCallum CD, Su B, Johnson AE: Factor VIla-tissue factor: functional importance of protein-membrane interactions. Thromb Haemost 1997; 78:112-116. PMID: 9198138 
34. Le DT, Rapaport SI, Rao LVM: Studies of the mechanism for enhanced cell surface factor VIla/tissue factor activation of factor $\mathrm{X}$ in fibroblast monolayers after their exposure to $\mathrm{N}$-ethylmalemide. Thromb Haemost 1994; 72:848-855. PMID: 7740453

35. Roy S, Hass PE, Bourell JH, Henzel WJ, Vehar GA: Lysine residues 165 and 166 are essential for the cofactor function of tissue factor. J Biol Chem 1991; 266:22063-22066. PMID: 1939226

36. Huang Q, Neuenschwander PF, Rezaie AR, Morrissey JH: Substrate recognition by tissue factor-factor VIla. J Biol Chem 1996; 271:21752-21757. PMID: 8702971

37. Ruf W, Miles DJ, Rehemtulla A, Edgington TS: Cofactor residues lysine 165 and 166 are critical for protein substrate recognition by the tissue factor-factor VIla protease. J Biol Chem 1992; 267:6375-6381. PMID: 1372908

38. Kirchhofer D, Lipari MT, Moran P, Eigenbrot C, Kelley RF: The tissue factor region that interacts with substrates factor IX and Factor X. Biochem 2000; 39:7380-7387.

39. Gajsiewicz JM, Nuzzio KM, Rienstra CM, Morrissey JH: Tissue Factor Residues That Modulate Magnesium-Dependent Rate Enhancements of the Tissue Factor/Factor VIla Complex. Biochem 2015; 54:4665-4671.

40. Ruf W: Role of thiol pathways in TF procoagulant regulation. Thromb Res 2012; 129 Suppl 2:S11S12. doi: 10.1016/j.thromres.2012.02.020 PMID: 22401798

41. Kothari H, Rao LVM, Pendurthi UR: Cys186-Cys209 disulfide-mutated tissue factor does not equal cryptic tissue factor: no impairment in decryption of disulfide mutated tissue factor. Blood 2010; 116:502-503.

42. Wolberg AS, Monroe DM, Roberts HR, Hoffmann MR: Tissue factor de-encryption:ionophore treatment induces changes in tissue factor activity by phosphatidylserine-dependent and -independent mechanisms. Blood Coag Fibrinol 1999; 10:201-210. 